school in Kenya nor the first in Tanganyika has yet reached a School Certificate form, though both are due to do so within the next two years. Meanwhile, only a few girls have qualified for matriculation through predominantly boys' schools. Most of the women accepted for Makerere under "Special Entry" conditions have had some years teaching experience in primary schools, and, though they often find it a hard struggle to survive academically, some of them develop during their life at the College a hitherto hidden maturity. The whole question of the College's contribution to women's education is at present being studied with the help of an advisory committee of persons engaged in this sphere in the territories.

Like the sister Colonial university colleges, Makerere is in special relationship with the University of London so far as its courses for the B.A. and B.Sc. degrees are concerned. The College takes the initiative in putting forward its own proposals for syllabuses which it submits to the relevant Boards of Study of the University. The process of negotiation up to the final stages is carried through informally between opposite numbers. Similarly, the College examiners submit the first drafts of the Intermediate and Final degree papers and do the first marking of the scripts, which are then sent by air mail to the University of London examiners for the final determination of results. It is too soon to assess the full potentialities of the scheme.

If Makerere is to serve East Africa's needs as a university it will also have to become a centre of research. A start has been made. There are two research schemes for which the College has taken responsibility but which are separately financed from Colonial Development funds - the East African Institute of Social Research under the directorship of Dr. Audrey Richards, and a scheme to investigate malnutrition and anæmia under Prof. Eric Holmes, the head of the College's physiology department.

'The most critical problem at Makerere is the recruitment of staff. Not only will Makerere have to find men and women with the necessary specialized qualifications to teach at university-level, but among them those who are willing to offer their experience and skill and adapt them to the teaching problems and the opportunities of an African university college.

\section{STATISTICS FOR COLONIAL AGRICULTURE}

$\mathrm{I}_{\mathrm{H}}^{\mathrm{N}}$ January 1947 the Agricultural Economics Research Institute of the University of Oxford was asked to undertake a review of the organization and methodology of agricultural statistics in Colonial territories, in the light of reports received from the various Colonial Administrations.

The report, prepared by Mr. K. E. Hunt of the Institute*, opens with a useful selection of statistical series for first study, followed by a programme, in broad outline, for obtaining such data, first of all on a small (village) scale, with later developments either more intensive or more extensive. The first section concludes with a suggested set of definitions of terms used in agricultural statistics. Succeeding sections

- Statistics for Colonial Agriculture-Report on the Organisation of Recording and Estimating. Colonial Research Publications No. 11.
H.M.S.O.) $7 s .6 d$. net. deal in more detail with techniques appropriate to the various kinds of information sought. A glance at the 'contents' gives some idea of the comprehensive nature of the review. There are sections on village studies (3), extensive surveys (4), crop yield and production estimation (7), crop production forecasting (8), mixed crops (9), tree crops (10), land utilization (11), livestock populations and output (12), and two sections on marketing and distribution. With the more intractable problems of the later sections, the detail is naturally less. Under these headings many other important practical topics, such as recording technique, approach to selected communities, sample selection, correction of bias in eye estimation, crop cutting techniques, etc., are discussed.

Various methods and the results of much valuable experience both in office and field-in preparation, planning, inauguration, execution, analysis and reporting-are thus brought together. By clearly defining the main features in each of these situations, whether difficulties, possible approaches or points to consider, and including actual examples, the report makes most informative and stimulating reading. Many suggestions will need but slight modification to suit the locality. Matters, more of experience than principle, such as preparation of schedules and questionnaires, measuring areas, tabulation, analysis and records are dealt with in the appendixes.

The extremes of excessive detail but limited application and of discussions in abstract general terms are alike avoided; instead, principles are described in homely terms, statistical refinements not being considered necessary at the present. This publication will surely do much to satisfy a long-felt need.

G. E. HonnetT

\section{ABORIGINAL RAIN-MAKERS}

TN many parts of Australia droughts have an 1 appalling effect upon the sources of food of an aboriginal tribe, and it is not surprising to know that both the black and the white man have sought to stimulate Nature to greater generosity with her lifegiving rains. The ways in which they seek to induce rain are described by Frederick D. McCarthy in the Australian Museum Magazine (10, No. 8).

The aborigines desire rain at specific times both for individual and for group or collective purposes. A man attempts to create a storm or shower to obliterate footsteps when eloping with a woman, or, if he is a criminal, escaping the vengeance of his victim's friends. The making of rain, however, becomes a serious matter when it is organized by a local group whose reason may be the overwhelming one of survival in a drought-stricken land, or the desire to carry out important seasonal ceremonies upon which the life-giving power of the community depends ; a local group may wish to punish another one by sending storms to spoil their hunting and fishing.

The rites are usually performed during the day; but the Yaroinga of Queensland have one method in which special songs are sung during the night. The rain-maker uses his deep knowledge of local weather conditions as a guide and performs his rites in seasons and at times when rain can reasonably be expected; as a result his efforts are often rewarded with success. In many tribes the rites may be performed by any individual; but as a rule there are 
one or more rain-makers in a local group who either confine their magical activities to this sphere or are fully initiated medicine-men. In most tribes women cannot witness the rites; in others they participate in some methods or perform a simple type of magical act themselves.

The methods employed by the rain-makers are surprisingly varied, originating as they do in a dream, as a traditional rite performed by the dream-people, or from an incident in daily life which has been followed by rain. Many of the methods are imitative of clouds and falling rain, and of aquatic animals; others seek to persuade the ancestral beings to release the rain, and some medicine-men believe they can go up to the sky to open the clouds.

The Dieri and other tribes of the Lake Eyre district believe that the mura-mura, their spiritual ancestors who made and inhabited the earth in the dream-time prior to man's occupation, now live in the sky, and some of them have to be influenced by ceremonies to release the rain from the clouds.

In south-east Australia storms of wind and rain, and also floods, were believed to be sent by enemies to disturb hunting and fishing activities. The Kurnai of Gippsland squirted water from the mouth in the direction from which rain usually came, and sang magical rain chants acquired in dreams by both men and women.

In Arnhem Land pounded bark (used for poisoning fish) is wrapped in grass, weighted in stones, and taken out into either salt or fresh water by a man until his shoulders are covered; here he drops the bundle, sings a song about falling rain, and pushes the water with his hands to represent the rain splashing on its surface. He expects the clouds to form in about three days and the rain to come on the fourth day after this rite. Here, too, a large bundle of green grass fashioned into a human image is buried and when it swells up rain is expected to fall. The rain is stopped by taking the grass out of the water or ground and spreading it out to dry.

\section{AIR MASS CLIMATOLOGY OF THE BRITISH ISLES}

COME simple facts about the air mass climatology $S$ of the British Isles, such as the difference between the relative coldness of east and the relative warmth of south-west winds in winter, have been common knowledge for ages. In the second and third decades of this century the Norwegian school of meteorologists, led by V. and J. Bjerknes, elaborated the ideas of Shaw, Lempfert and others to depict the atmosphere as 'organized' not only into cyclonic and anticyclonic systems but also into warm and cold air masses (often referred to respectively as tropical and polar air) with different life-histories. The interplay of different air masses was shown to produce the day-to-day weather changes of the temperate and polar regions.

In a recent Air Ministry/Meteorological Office* memoir, which is a contribution to synoptic climatology, Dr. J. E. Belasco has investigated the more important physical properties of the atmosphere over the British Isles in twenty-one subdivisions of

* Air Ministry : Meteorological Office. Geophysical Memoir No. By Dr. J. E. Belasco. Pp. 34. (London: H.M.S.O., 1952.) 2s. 6d. net. tropical and polar air, using surface and upper-air data for the period 1931-45. The generalized tracks over which the air masses reach the British Isles are shown by maps, and the frequency of occurrence of the air masses and the average temperature and humidity of the atmosphere in them at the surface at Kew Observatory and in the upper air up to 450 mb. (about $6 \mathrm{~km}$.) over the British Isles are set out in tables and thermodynamic diagrams. There is also a discussion of the changes of temperature and humidity which maritime tropical and direct polar air masses undergo as, on their way to the British Isles, they pass over a surface respectively colder and warmer than their lowest layers. With the aid of this memoir, it has now become possible for the first time to explain some aspects of the climate of the British Isles in terms of the incidence and of the physical properties of different air masses instead of describing them statistically by the usual presentation of means and extremes.

The discussion shows that the correspondence between air mass and wind direction is quite rough and far from unique. Thus, north-west winds usually bring a cold air mass with a large fall of temperature with height and rssociated showery weather; but when an anticyclone remains stationary westward of Ireland, such winds can bring air originating over the sub-tropical Atlantic which has been cooled from below on its way. Again, polar air of a particularly unstable type can come with a south wind having travelled around a stationary depression centred south-west of Ireland. Quite the coldest air mass is, as is well known, the one which comes in winter from Russia and reaches the British Isles from the east or south-east. This air mass has in January a mean maximum temperature of $31^{\circ} \mathrm{F}$. at Kew. The warmest air mass in January comes from the Madeira area and has a mean maximum of $53^{\circ} \mathrm{F}$. at Kew. In July the temperature differences between the coldest and warmest air masses are nearly as great as in January. Air of west Mediterranean origin has at Kew in July a mean maximum of $82^{\circ} \mathrm{F}$. and air direct from the sea north of Norway a mean maximum of $64^{\circ}$. The differences of temperature between air masses in the upper air are larger than at the surface because the primary heating and cooling occur at the surface.

Dr. Belasco's memoir will be of value not only to those seeking a physical explanation of British climate, but also to the weather forecaster in stating the weather to be expected in an air mass the arrival of which he has foretold.

\section{PAPER PULP RESEARCH AT THE DEHRA DUN RESEARCH INSTITUTE}

TNVESTIGATIONS on the pulping of illuk grass (Imperata arundinacea) by the soda and the mono-sulphite processes* have been undertaken at the Forest Research Institute, Dehra Dun, at the request of the Ceylon Government, which forwarded samples for the purpose, with the view of ascertaining the respective economics and suitability of the two

* Indian Forest Bulletin No. 145: Pulping of Illuk Grass (Imperata arundinacea) by Soda and Mono-Sulphite Processes. By Chattar lications, 1951.) Anuas $8 ; 9 d$. 